\begin{tabular}{|c|c|c|}
\hline & $\begin{array}{c}\text { International Journal of Current Research in } \\
\text { Biosciences and Plant Biology } \\
\text { EXCELLENT } \\
\text { PUBLISHERS }\end{array}$ \\
Volume $4 \bullet$ Number 7 (July-2017) $・$ ISSN: 2349-8080 (Online) \\
Journal homepage: www.ijcrbp.com
\end{tabular}

\title{
Improving Agricultural Rain Water Use Efficiency by Land and Nutrient Management and the Intercropping System in Farmers' Fields in Mali
}

\author{
Diakalia Sogodogo ${ }^{1}$, Béjamé Coulibaly ${ }^{2}$, Bouya Traoré ${ }^{3}, \mathbf{M}^{\mathrm{me}}$ Dao Rokia Coulibaly ${ }^{4}$, Ibrahima Dramé ${ }^{5}$, \\ Brahima Diabaté $^{6}$ and Souleymane Koumaré ${ }^{7}$
}

\author{
${ }^{1}$ Agronome système, IER - ESPGRN/SRA Cinzana, Mali \\ ${ }^{2}$ Agronome (Gestion Intégrée de la Fertilité des Sols), IER - ESPGRN/SRA Cinzana, Mali \\ ${ }^{3}$ Agronome (Fertilisation des sols), CRRA de Gao/IER/Mali \\ ${ }^{4}$ Agronome-Vulgarisation Agricole-Direction Régionale de l'agriculture de Ségou, Mali \\ ${ }^{5}$ Agronome, Point focal Sahel 21 à Didiéni, Mali \\ ${ }^{6}$ Agronome, Point focal AMAPROS à Ségou, Mali \\ ${ }^{7}$ Agroforestier, Point focal GRAADECOM à Sikasso, Mali
}

*Corresponding author.

\begin{tabular}{|c|c|}
\hline Abstract & Article Info \\
\hline \multirow{9}{*}{$\begin{array}{l}\text { An experiment conducted in farmers' fields during two consecutive years was comparing } \\
\text { sowing crops on simple ridging (one local technique of soil tillage in the area of the study) } \\
\text { to sowing crops in half-moon (an innovative technique) to see their effects on the } \\
\text { intercropping system performance and on the rain water use efficiency (RWUE). The } \\
\text { slope of experiment fields all located on abandoned land for decades, was less than } 3 \% \text {. } \\
\text { Experiment was conducted in the field of } 12 \text { collaborating farmers in a dispersed Fischer } \\
\text { block lay out where each farmer was representing one replication. Crop yield and decade } \\
\text { rainfall amount were recorded in each site. Data analysis has shown the good yield of } \\
\text { sorghum-cowpea intercropping in half moon. Crop management and rainfall distribution } \\
\text { were the causes of bad performance of crops sown on simple ridging. Rain water use } \\
\text { efficiency was the best in the half moon cropping system. In conclusion, the proposed } \\
\text { alternative cropping system is involving intercropping in half moon and the application of } \\
\text { mineral fertilizer microdose to improved varieties. This allows the use of abandoned land. } \\
\text { The use of cowpea one grain legume crop in the system allows improving farmer income } \\
\text { and stimulating the use of mineral fertilizer in sorghum cropping. }\end{array}$} & $\begin{array}{l}\text { Accepted: } 11 \text { June } 2017 \\
\text { Available Online: 06 July } 2017\end{array}$ \\
\hline & Keywords \\
\hline & Farmer \\
\hline & Half-moon \\
\hline & Simple ridging \\
\hline & Water use efficiency \\
\hline & \\
\hline & \\
\hline & \\
\hline
\end{tabular}

\section{Introduction}

Mali covers an area of 1.241 million $\mathrm{km}^{2}$ and extends between the 10th and 25th degree of north latitude, between 4th degree longitude east and 12th degree west longitude. It has a population of $14,528,662$ which increases at a rate of 3.6\% / year (INSTAT, 2011). With such a rate, the population will double every 20 years with a constantly increasing food demand. This development is not without adverse consequences on natural resources. In traditional shifting agriculture, it will require more land, water, fertilizer, labor. These 
various resources are not inexhaustible because the limits of village agricultural soils are known. Rainfed agriculture is central to food production in sub-Saharan Africa (Cooper and Al, 2008). The rainfall of the study area varies between 300 and $1000 \mathrm{~mm}$ and is characterized by great inter - annual variability and poor distribution in space. The length of the growing season varies between 75 and 120 days (Sivakumar, 1991). In Mali, cropland is poor in nutrients necessary for good plant growth (Van Der Pool, 1992). The average yield of millet and sorghum is $600 \mathrm{~kg}$ of grain/ha. But the cereal balance of the 2006/2007 crop year showed a cereal surplus of 613,000 tons of cereals combined (Ministry of Agriculture, 2008). The maintenance of such a cereal surplus is not without its problems. Continuous land use, runoff and erosion create differences in fertility within and between cropping areas (Penning De Vries and Djitéye, 1982). The combination of rainfall and low fertility factors in cropland is reflected in the yield variability of the major crops (millet, sorghum, cowpea and maize) of smallscale producers from one year to the next.

It is therefore necessary to look for cropping systems that increase the production of smallholder farmers through the efficient use of available resources at the level of their farms. The association of cultures is a system of cultivation widely practiced by peasants. It provides farmers with agronomic, economic benefits and increases the efficient use of resources. The cultivation of more than one species of plant simultaneously in the same field during the same growing season is a means of sustainable production improvement (Baldy, 1963). But a combination of this system with soil and water conservation techniques appears to give more sustainability to the production of the system.

Our working hypothesis is that the combination of crop association and water conservation techniques in the field would improve crop yield, peasant income and efficient use of rainwater. The objective of this research is to evaluate different techniques of tillage, the agronomic effects and the productivity of sorghumcowpea association, and the effects of this association on the efficient use of rainwater (RWUE: rain water use efficiency).

\section{Materials and methods}

To undertake this experimentation among farmers, the Institute for Rural Economy, the research institution for the IDRC-funded Integrated Water and Nutrient Management for Sustainable Agricultural Production in the Sahel project, Developed a partnership with NGOs (1) Grassroots Research and Community Development Assistance Group (GRAADECOM) in Sikasso in the south, (2) Mali Association for the Promotion of the Sahel (AMAPROS) in Ségou in The center and (3) SAHEL21 of Didiéni in the north (see Fig. 1). These NGOs were responsible for the identification of collaborating farmers and experimental sites in their respective areas of intervention and labor logistics.

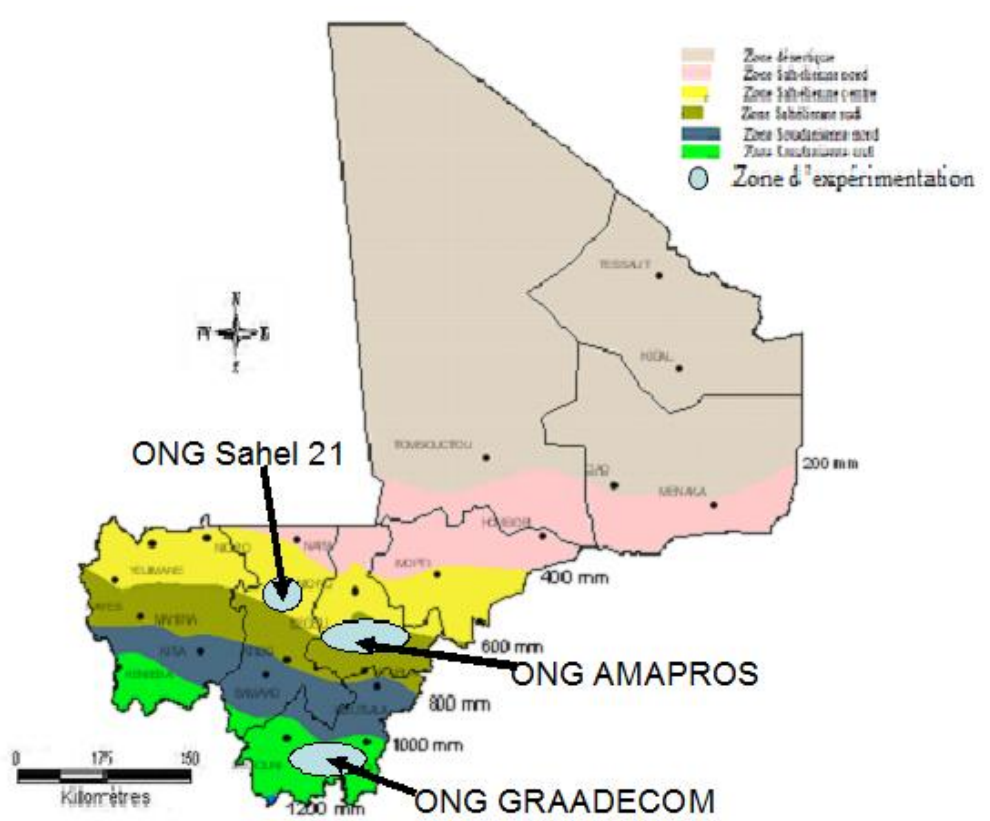

Fig. 1: Area of experiment in Mali (Source : LABOSEP of Sotuba, 2000). 


\section{The experimental site}

Experimentation was carried out in three agro-climatic zones and the experimental villages received average rainfall of two years (Fig. 1). The village of Sielle in the Sahelian zone, supervised by the NGO SAHEL21, received on average $452 \mathrm{~mm}$ of rain in 32 days (Fig. 2).

The village of Ntogosso in the southern limit of the Sahelian zone, which is supervised by the NGO AMAPROS, received an average height of $465 \mathrm{~mm}$ of rain / year in 40 days (Fig. 3). The village of Siramana in the Sudanian zone supervised by the NGO GRAADECOM had an average rainfall of $975 \mathrm{~mm}$ of rain / year in 62 days (Fig. b4). In the three sites, the agricultural campaigns were characterized by droughts at the end of the cycle of vegetation.

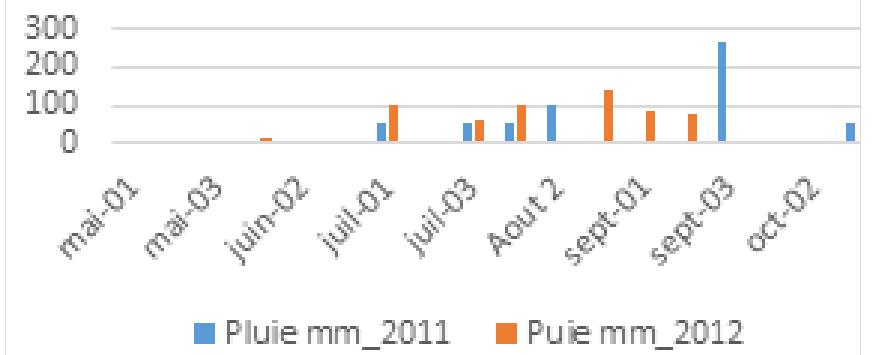

Fig. 2: Annual rainfall of the village of Sielle in 2011 and 2012 in Mali.

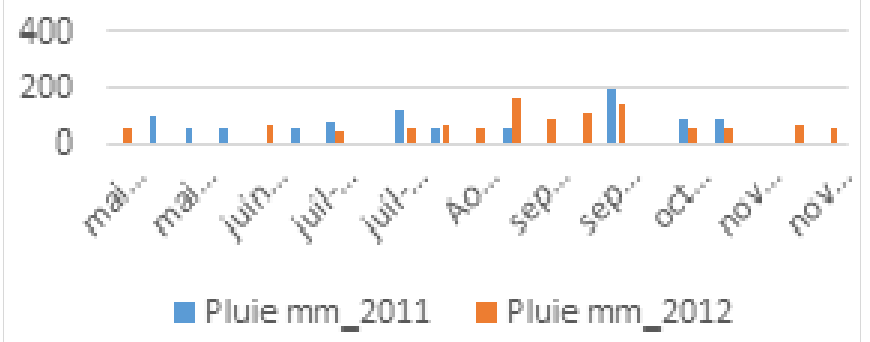

Fig. 3: Annual rainfall of the village of Siramana in 2011 and 2012 in Mali.

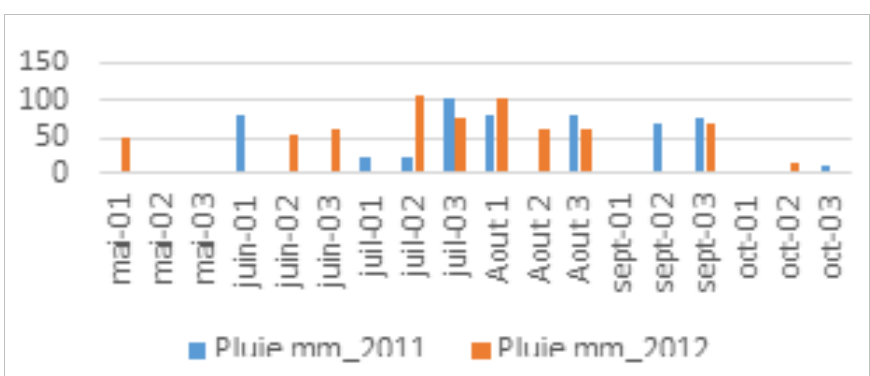

Fig. 4: Annual rainfall of the village of Togosso in 2011 and 2012 in Mali.

\section{Plant varieties used}

The varieties used in sub-block I of the experiment were sorghum CSM388 and cowpea Sankaranka all of late cycle (100 to 120 days) in Siramana in the rainier southern zone, sorghum Jakumbè and cowpea Korobalen all of early cycle (90 to 100 days) in the Sahelian zones of NTogosso and Siellé. The improved varieties came from the Institute of Rural Economy. In sub-block II (under control block), local varieties of sorghum and cowpea were used.

\section{Experimental apparatus}

The experimental device was a dispersed Fischer block where each farmer represented a repetition. The block was divided into two sub-blocks of three treatments each (pure sorghum crop, pure cowpea crop and the sorghumcowpea crop combination). The elementary parcel was $14 \mathrm{~m} \times 8 \mathrm{~m}$ on the side. Experimentation was carried out in 12 collaborating peasants (4 in Siellé, 4 in Siramana and 4 in NTogosso). In the improved system block (T1, T2 and T3), crops were sown in the half-moon made at the beginning of the rainy season.

In the T1 (pure sorghum crop), sorghum was sown at $0.75 \mathrm{~m} \times 0.5 \mathrm{~m}$ and split at 2 plants / pole. The half moon has 4 rows of seedlings and has 42 pockets of sorghum i.e., 126 pits / elementary plot and 11,250 pods / ha. The DAP was supplied at a rate of $2 \mathrm{~g} / \mathrm{pit}, 252$ g/elementary plot and $22.5 \mathrm{~kg} / \mathrm{ha}$.

In T2 (pure cowpea crop), cowpea is sown at $0.75 \mathrm{~m} \times$ $0.5 \mathrm{~m}$ and split at 2 plants / pocket. The half moon has 4 rows of seedlings, 42 cowpea pits, i.e., 126 pits/elementary plot and 11,250 pods/ha. The DAP was supplied at a rate of $2 \mathrm{~g} / \mathrm{pit}, 252 \mathrm{~g} /$ elementary plot and $22.5 \mathrm{~kg} / \mathrm{ha}$.

In the T3 (sorghum-cowpea crop association), sorghum is sown at $0.75 \mathrm{~m} \times 0.5 \mathrm{~m}$ and split at 2 plants/pole. In the half moon, there were 4 seed lines with 42 pockets of sorghum (126 pairs/elementary plot per hectare 11,250 pairs and 22,500 plants). At a rate of $2 \mathrm{~g} /$ pound, sorghum received $22.5 \mathrm{~kg}$ of DAP/ha. Cowpea was sown in each second row of sorghum. There were $1 \mathrm{~m}$ between pockets on the line and $1.5 \mathrm{~m}$ between lines. In the plot, there are 21 cowpea pits (63 pockets/plot per hectare 5,625 pockets and 11,250 plants). The cowpea received $11.25 \mathrm{~kg}$ of DAP/ha at the rate of 2 g/pit. 
In the control block (T4, T5 and T6), the crops were planted on a simple trenching of the crop season. There were 11 rows of seedlings in each elementary plot. In pure cultivation, sorghum and cowpea were sown at a distance of $0.8 \mathrm{~m}$ between rows and $0.8 \mathrm{~m}$ on the line, and split at 2 plants per pole (15 625 pods/ha, i.e., 31,250 plants/ha). In the association, sorghum main crop was sown at its pure culture density $(0.8 \mathrm{~m} \times 0.8 \mathrm{~m}$, started at 2 plants/pk). Cowpea was sown in each second inter-sorghum pitch $(1.6 \mathrm{~m}$ between pole and $1.6 \mathrm{~m}$ between lines: 3,906 pods/ha and 7,812 plants/ha). The experimental design is shown in Fig. 5.

Planting was carried out during the second and third decades of July and harvests during the second and third decades of October. The input was made with Excel and the analysis of variance with the software INSTAT v3.6.

\section{Block I}

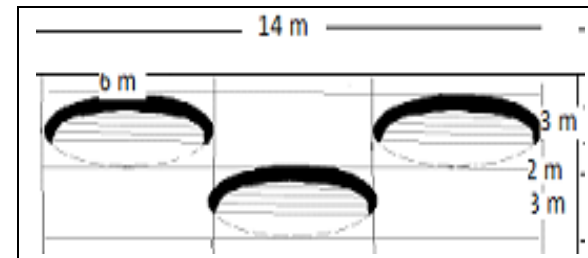

T1: Cultivation pure sorghum $+1 / 2$ moon + Microdose DAP + Improved variety

Block II

T4: Cultivation pure sorghum + ridge without fertilizer + Local variety

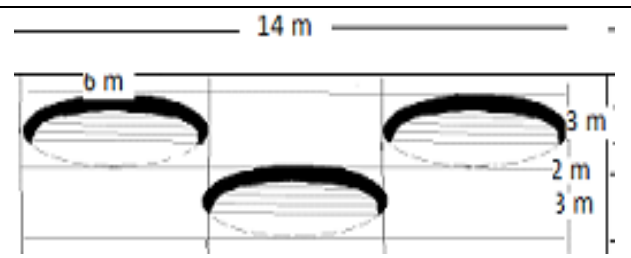

T2: Cultivation pure cowpea $+1 / 2$ moon + Microdose DAP + Improved variety

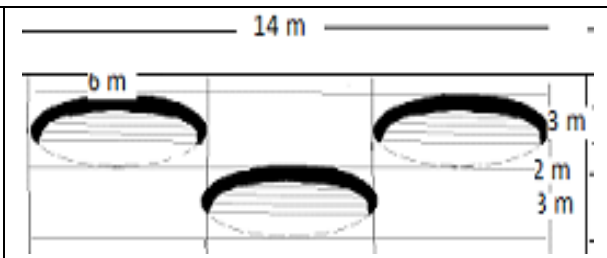

T3: Sorbian-Cowpea Association + 1/2 Moon + DAP Microdose + Improved variety

Fig. 5: Experimental design of the present study.

\section{Rain water use efficiency}

This variable measures the capacity of the cropping system to convert water into grain or plant biomass. It includes both the use of water stored in the soil and the rain received during the growing season (GRDC 2009). It is determined by the formula below:

Rain water use efficiency $(\mathrm{RWUE})=\frac{\text { Total yield of grain or biomass in } \mathrm{kg}}{\text { Total rainfall height in } \mathrm{mm}}$

\section{The Land Equivalent Ratio (LER)}

It makes it possible to evaluate the productivity of the associations in relation to the monocultures and is defined as the area necessary for each crop to produce in monoculture the same yield as one ha of the same crop in a system of association.

It is calculated as follows:

$$
\text { LER }=\frac{\text { Culture yield of } A \text { in combination }}{\text { Pure culture yield of } A}+\frac{\text { Crop yield of } B \text { in association }}{\text { Pure culture yield of } B}
$$

If the LER is $<1$, the culture association is not advantageous over the pure culture. If LER> 1: a larger area would be needed to produce the same amount of product when the plants are grown in monoculture compared to the associations. In such cases, the associations give better yields compared to the performance of the same crops in monoculture systems (Fairhurst, 2017).

\section{Results and discussion}

\section{Crop yield}

Sorghum grain: The yield of sorghum varied significantly between tillage techniques and between sites (Table 1). The best yield was obtained at Siramana with 1731.5 and $1012.5 \mathrm{~kg}$ of grain / ha respectively in the half-moon and single ridges. Sorghum benefits more from the micro-dose of fertilizer ( $2 \mathrm{~g}$ of DAP / pole at sowing) in the half-moon.

Compared to the half-moon, the sorghum-cowpea crop was grown on simple ridges prepared at the beginning of the crop season, resulting in yield reductions of sorghum grain of $-102 \%$ at Siellé, $-71 \%$ at Siramana and $-44 \%$ in NTogosso.

Grain of cowpea: It is at Siramana where the best yields of cowpea grain have been recorded (831 and 362 $\mathrm{kg} /$ ha respectively in the half-moon and single ridges). The addition of $2 \mathrm{~g}$ of DAP / pellet to sowing 
significantly improved the yield of cowpea in the halfmoon. The shift from single crop cultivation to single- row crops resulted in yield reductions of $-44 \%$ at Siellé, $-229 \%$ at Siramana and $-174 \%$ at NTogosso (Table 2).

Table 1. Yield of sorghum grain in sorghum-cowpea association in peasant fields, Mali / Sorghum grain yield in the intercropping sorghum-cowpea in Farmers' fields in Mali.

\begin{tabular}{lllllll}
\hline \multirow{2}{*}{ Villages } & \multicolumn{2}{l}{ In the half moon } & \multicolumn{4}{l}{ In simple ridging } \\
\cline { 2 - 7 } & $\mathbf{2 0 1 1}$ & $\mathbf{2 0 1 2}$ & Average & $\mathbf{2 0 1 1}$ & $\mathbf{2 0 1 2}$ & Average \\
\cline { 2 - 7 } & $\mathbf{( * * )}$ & $(*)$ & & $(* *)$ & $(* *)$ & 600 \\
\hline Siellé & 1100 & 1325 & 1212.5 & 525 & 675 & 1012.5 \\
Siramana & 1825 & 1638 & 1731.5 & 1025 & 1000 & 425 \\
NTogosso & 625 & 600 & 612.5 & 375 & 475 & \\
Standard error & 138.9 & 189.6 & & 113.3 & 87.4 & \\
CV\% & 23.5 & 31.9 & & 35 & 24.4 & \\
\hline
\end{tabular}

$(* *)$ : Highly significant difference at $1 \%,(*)$ : Significant difference at $5 \%$.

Pure culture of sorghum in the half moon: Siellé= 2011: $1425 \mathrm{~kg} / \mathrm{ha}$ and 2012: $1525 \mathrm{~kg} / \mathrm{ha}$; Siramana= 2011: $2000 \mathrm{~kg} / \mathrm{ha}$ and 2012: $2075 \mathrm{~kg} / \mathrm{ha}$; NTogosso= 2011: $1000 \mathrm{~kg} / \mathrm{ha}$ and 2012: $800 \mathrm{~kg} / \mathrm{ha}$

Pure culture of sorghum on single log: Siellé=2011: $700 \mathrm{~kg} / \mathrm{ha}$ and 2012: $850 \mathrm{~kg} / \mathrm{ha}$; Siramana= 2011: $1175 \mathrm{~kg} / \mathrm{ha}$ and 2012: $1200 \mathrm{~kg} / \mathrm{ha} ;$ NTogosso= 2011: $425 \mathrm{~kg} / \mathrm{ha}$ and 2012: $525 \mathrm{~kg} / \mathrm{ha}$.

Table 2. Cowpea grain yield in the sorghum-cowpea association in peasant fields, Mali / Cowpea grain yield in the intercropping sorghum-cowpea in farmers' fields in Mali.

\begin{tabular}{|c|c|c|c|c|c|c|}
\hline \multirow{3}{*}{ Villages } & \multicolumn{3}{|c|}{ In the half moon } & \multicolumn{3}{|c|}{ In the simple ridging } \\
\hline & 2011 & 2012 & Average & 2011 & 2012 & Average \\
\hline & $(*)$ & $(* *)$ & & $(*)$ & $(* *)$ & \\
\hline Siellé & 475 & 500 & 487.5 & 375 & 300 & 337.5 \\
\hline Siramana & 912 & 750 & 831.25 & 325 & 400 & 362.5 \\
\hline NTogosso & 375 & 275 & 325 & 112.5 & 125 & 118.75 \\
\hline Standard error & 137.1 & 74.07 & & 63.87 & 44.88 & \\
\hline $\mathrm{CV} \%$ & 36 & 29.1 & & 27 & 32 & \\
\hline
\end{tabular}

$(* *)$ : Highly significant difference at $1 \%,(*)$ : Significant difference at $5 \%$.

Pure Cowpea Crop in the Half Moon: Siellé= 2011: $575 \mathrm{~kg} / \mathrm{ha}$ and 2012: $625 \mathrm{~kg} / \mathrm{ha}$; Siramana= 2011: $1200 \mathrm{~kg} / \mathrm{ha}$ and 2012:

$1125 \mathrm{~kg} / \mathrm{ha}$; NTogosso= 2011: $350 \mathrm{~kg} / \mathrm{ha}$ and 2012: $575 \mathrm{~kg} / \mathrm{ha}$

Cultivation of pure cowpea on single log: Siellé=2011: $450 \mathrm{~kg} / \mathrm{ha}$ and 2012: $425 \mathrm{~kg} / \mathrm{ha}$; Siramana $=2011: 825 \mathrm{~kg} / \mathrm{ha}$ and

$875 \mathrm{~kg} / \mathrm{ha}$; NTogosso = 2011: $275 \mathrm{~kg} / \mathrm{ha}$ and 2012: $350 \mathrm{~kg} / \mathrm{ha}$.

\section{Land equivalent ratio}

In the half-moon, the equivalent surface ratios recorded were 1.63 at Siellé, 1.56 at Siramana and 1.43 at 1.45 at NTogosso (Fig. 6). The average partial LER of cowpea is 0.76 vs. 0.78 for sorghum, the main crop. The halfmoon appears as a technique favorable to a good grain yield of the additional crop.

On simple ridges, the equivalent surface ratios obtained were 1.54 at Siellé, 1.27 at Siramana and at NTogosso (Fig. 7). The average partial LER of cowpea is 0.52 vs. 0.84 for sorghum. The performance of cowpea in this tillage system was the lowest.

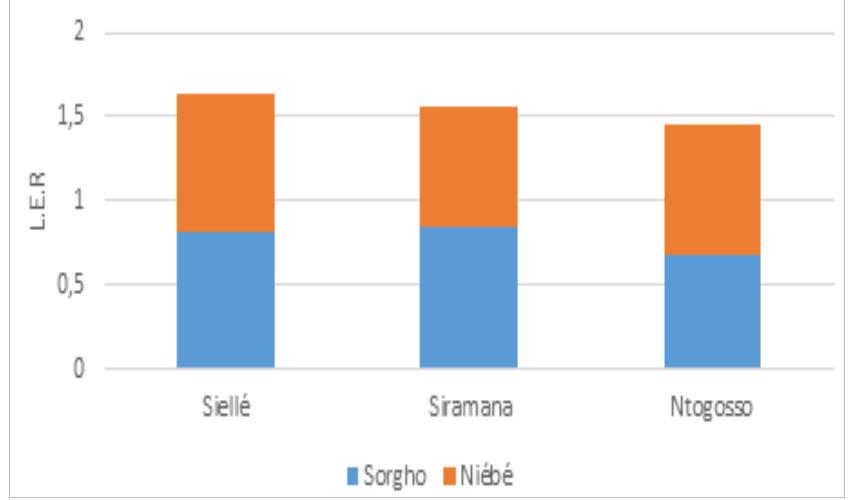

Fig. 6: Equivalent area ratio in the sorghum-cowpea association in the half-moon in Mali. 


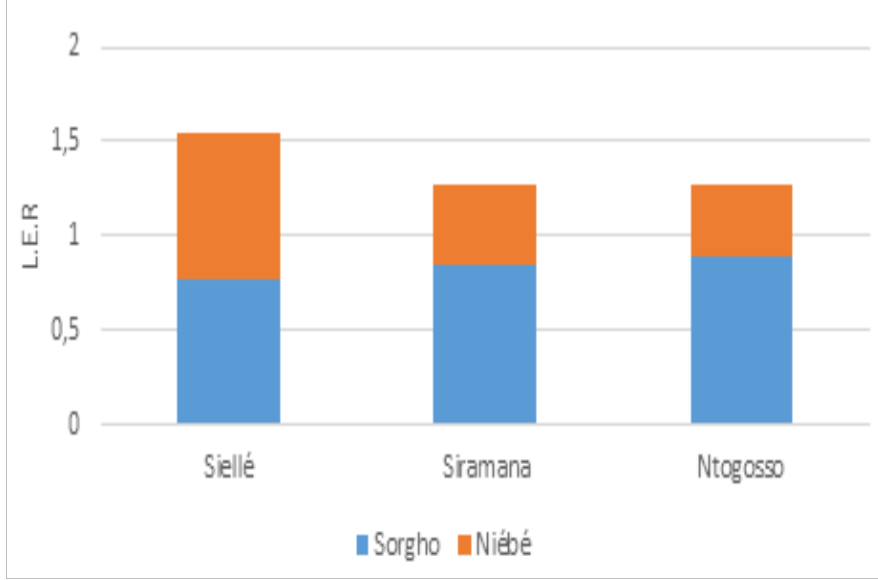

Fig. 7: Equivalent area ratio in the sorghum-cowpea association in the simple ridging in Mali.

\section{Rain water use efficiency}

Table 3 shows the RWUE values obtained at the different sites by combining sorghum-cowpea crops in the half-moon. The combination of cultures yielded mean values of $3.77 \mathrm{~kg}$ of grain $/ \mathrm{mm}$ of rain at Siellé; 2.67 in Siramana; 2.01 to NTogosso.

Pure sorghum yielded as average RWUE ( $\mathrm{kg}$ of grain / ha / $\mathrm{mm}$ of rain), 2.69 at Siellé 2.10 at Siramana and 1.32 at NTogosso. Pure cowpea crop yielded average RWUE of 1.33 at Siellé, 1.20 at Siramana and 0.99 at NTogosso. The mean values of RWUE obtained in the combination are higher in all sites than in pure sorghum and cowpea cultures taken individually.

Table 3. Information on rain water use efficiency in intercropping system in Mali.

\begin{tabular}{|c|c|c|c|c|c|c|c|}
\hline \multirow{3}{*}{ Localities } & \multicolumn{7}{|c|}{ Grain yield in $\mathrm{kg}$ / ha } \\
\hline & \multicolumn{3}{|c|}{ Intercropping } & \multicolumn{4}{|c|}{ Sole crops } \\
\hline & $\begin{array}{l}\text { Sorghum } \\
\text { kg/ha }\end{array}$ & $\begin{array}{l}\text { Cowpea } \\
\text { kg/ha }\end{array}$ & RWUE* & $\begin{array}{l}\text { Sorghum } \\
\text { kg/ha }\end{array}$ & RWUE & $\begin{array}{l}\text { Cowpea } \\
\text { kg/ha }\end{array}$ & RWUE \\
\hline \multicolumn{8}{|l|}{ Siellé } \\
\hline 2011 (404 mm) & 1100 & 475 & 3.90 & 1425 & 3.53 & 575 & 1.42 \\
\hline $2012(500 \mathrm{~mm})$ & 1325 & 500 & 3.65 & 925 & 1.85 & 625 & 1.25 \\
\hline \multicolumn{8}{|l|}{ Siramana } \\
\hline $2011(880 \mathrm{~mm})$ & 1825 & 912.5 & 3.11 & 2000 & 2.27 & 1200 & 1.36 \\
\hline $2012(1070 \mathrm{~mm})$ & 1638 & 750 & 2.23 & 2075 & 1.94 & 1125 & 1.05 \\
\hline \multicolumn{8}{|l|}{ NTogosso } \\
\hline $2011(460 \mathrm{~mm})$ & 625 & 375 & 2.17 & 1000 & 1.74 & 350 & 0.76 \\
\hline $2012(470 \mathrm{~mm})$ & 600 & 275 & 1.86 & 800 & 0.90 & 575 & 1.22 \\
\hline
\end{tabular}

RWUE* : Rain water use efficiency $(\mathrm{mm})$ : Total rainfall received during the growing season.

Table 4. Information on rain water use efficiency in the intercropping system on simple ridges in farmers' fields in Mali.

\begin{tabular}{|c|c|c|c|c|c|c|c|}
\hline \multirow{3}{*}{ Localités } & \multicolumn{7}{|c|}{ Grain yield in $\mathrm{kg}$ / ha } \\
\hline & \multicolumn{3}{|c|}{ Intercropping } & \multicolumn{4}{|l|}{ Sole crops } \\
\hline & $\begin{array}{l}\text { Sorghum } \\
\mathrm{kg} / \mathrm{ha}\end{array}$ & $\begin{array}{l}\text { Cowpea } \\
\text { kg/ha }\end{array}$ & RWUE* & $\begin{array}{l}\text { Sorghum } \\
\mathrm{kg} / \mathrm{ha}\end{array}$ & RWUE & $\begin{array}{l}\text { Cowpea } \\
\text { kg/ha }\end{array}$ & RWUE \\
\hline \multicolumn{8}{|l|}{ Siellé } \\
\hline 2011 (404 mm) & 525 & 375 & 2.23 & 700 & 1.73 & 450 & 1.11 \\
\hline $2012(500 \mathrm{~mm})$ & 675 & 300 & 1.95 & 550 & 1.10 & 425 & 0.85 \\
\hline \multicolumn{8}{|l|}{ Siramana } \\
\hline $2011(880 \mathrm{~mm})$ & 1025 & 325 & 1.53 & 1175 & 1.33 & 825 & 0.94 \\
\hline $2012(1070 \mathrm{~mm})$ & 1000 & 400 & 1.31 & 1200 & 1.12 & 875 & 0.82 \\
\hline \multicolumn{8}{|l|}{ NTogosso } \\
\hline 2011 (460 mm) & 375 & 112.5 & 1.06 & 425 & 0.92 & 275 & 0.60 \\
\hline 2012 (470 mm) & 475 & 125 & 1.28 & 425 & 0.90 & 350 & 0.74 \\
\hline
\end{tabular}

Table 4 shows the RWUE values obtained at the various sites by combining sorghum-cowpea crops on a single ridge. This association yielded mean values of $2.09 \mathrm{~kg}$ of grain/mm of rain at Siellé; 1.42 to Siramana; 1.17 to NTogosso. Pure sorghum yielded as average RWUE
( $\mathrm{kg}$ of grain/ha/mm of rain), 1.41 at Siellé 1.22 at Siramana and 0.91 at NTogosso. Pure cowpea yielded average RWUE of 0.98 to Siellé, 0.88 to Siramana and 0.67 to NTogosso. The mean values of RWUE obtained in the combination are higher in all sites than in pure 
sorghum and cowpea cultures taken individually. The pure cropping system and crop association use almost the same amount of water. However, the RWUE is the best in the cropping association system (Singh et al., 2013; Natarajan and Willey, 1980).

We observed a decrease in yield of sorghum and RWUE in the half moon at Siramana during the rainiest season (2012). Excessive rainfall can lead to flooding of crops and negatively affect crop development and yield (Zougmoré and Zida, 2011). The values of RWUE obtained in 2011 are all higher than those of 2012 in the three sites and it is on ridging that the lowest RWUE was recorded. The transport of a considerable soil from the ridges carried out of the field by heavy rains was observed at the sites. This is consistent with the problem of soil conservation and nutrients affecting RWUE that Browman and Scott (2009) had raised. The superiority of the RWUE in the half-moon is supported by good water infiltration, a good availability of nutrients to the plants and a reduction in the variability of the rains that this technique generates (Moumini et al., 2011).

Low crop - water productivity observed in the northern and southern parts of the Sahelian zone in the study area reflects low crop productivity (Bowman, 2007). The villages of Siellé and NTogosso have similar total rainfall but the RWUE values are highest at Siellé. This indicates a difference in the distribution of rainfall between sites and a need for additional water supply to crops during end-of-season crop droughts especially in the low RWUE village.

\section{Conclusion}

This study shows that the combination of sorghum and cowpea crops uses rainwater more efficiently than individual crops. In both tillage systems, the combination of crops, pure sorghum cultivation and pure cowpea cultivation represent the decreasing order in the efficient use of rainwater. These results are consistent with those obtained by Ofori et al. (2014) on maizecowpea association in Ghana.

\section{Conflict of interest statement}

Authors declare that they have no conflict of interest.

\section{Acknowledgement}

We would like to thank the International Development
Research Centre (IDRC) for financial support, and we acknowledge all the National technical partners, Farmers and Collaborators for their support in conducting the study.

\section{References}

Baldy, C., 1963. Cultures associées et productivité de l'eau. Ann. Agron. J. 14, 489-534.

Bowman, B.A.M., 2007. A conceptual framework for the improvement of crop-water productivity at different spatial scales. Agricult. Syst. 93, 43-60.

Bowman, A., Scott, B., 2009. Water use by crops and pastures insouthern NSW/PRImEFACt 214 For Profitable, Adaptive and Sustainable Primary Industries Primefacts. 6p.

Cooper, P. J. M., Dimes, J., Rao, K. P. C., Shapiro, B., Shiferaw, B., Twomlow, S. J., Verchot, L. P., Cooper, P., 2008. Coping better with current climatic variability in the rain-fed farming systems of sub-Saharan Africa: An essential first step in adapting to future climate change? Agric. Ecosyst. Environ. 126(1/2), 24-35.

Fairhurst, T., 2017. Manuel de Gestion Intégrée de la Fertilité des Sols/Africa soil health consortium/CTA).

GRDC, 2009. Water use efficiency. Fact sheet. Converting rainfall to grain/Northern Region/Grain Research \& Development Corporation. 6p.

INSTAT, 2011. Etat et structure de la population (thème 2). Analyse des résultats définitifs. 4ème Recensement général de la population et de l'habitat du Mali (RGPH-2009). Institut National de la Statistique. 88p.

Ministère de l'Agriculture, 2007. Recensement général de l'agriculture. Campagne agricole 2004-2005. Résultats définitifs - V. II. FAO/Coopération Française.

Moumini, S., Somda, J., Seynou, O., Zabré, S., Nianogo, N. J., 2011. Catalogue de bonnes pratiques d'adaptation aux risques climatiques au Burkina Faso. UICN.

Natarajan, M., Willey, R. W., 1980. Sorghum-pigeon pea intercropping and the effects of plant population density. 2. Resource use. J. Agric. Sci. 95(1), 59-65.

Ofori, E., Oteng-Darko, P., Berchie, J.N., Nimako, F.O., Yeboah, S., Owusu Danquah, E., 2014. Monitoring of soil moisture regime and water use efficiency under maize cowpea cropping system. Int. J. Curr. Microbiol. Appl. Sci. 3(10), 837-848.

Penning De Vries, F.W.T., Djiteye, M.A., 1982. La 
productivité des pâturages sahéliens. Une étude des sols, des végétations et de l'exploitation de cette ressource naturelle. Pudoc, Centre for Publishing and Documentation, Wageningen. 525p.

Singh, A. K., Singh, K. A., Bharati, R.C., Chadra, N., 2013. Response of intercrops and nutrient management on the performance of tobacco based intercropping system and assessment of system sustainability. Bangladesh J. Bot. 42(2), 343-348.

Sivakumar, M.V.K., 1991. Drought spells and drought frequencies in West Africa. Research Bulletin No. 13. Patancheru, India: International Crops Research Institute for the Semi-Arid Tropics. 181p.

Van Der Pol, F., 1992. Soil mining. An unseen contributor to farm income in southern Mali. Bulletin 325. Royal Tropical Institute. Amsterdam, The Netherlands.

Zougmoré, R., Zida, Z., 2011. Récupération Agronomique desterres encroûtées par la technique de demi-lune. FICHE TECHNIQUE $\mathrm{N}^{\circ} 5$.

\section{How to cite this article:}

Sogodogo, D., Coulibaly, B., Traoré, B., Coulibaly, M. D. R., Dramé, I., Diabaté, B., Koumaré, S., 2017. Improving agricultural rain water use efficiency by land and nutrient management and the intercropping system in farmers' fields in Mali. Int. J. Curr. Res. Biosci. Plant Biol. 4(7), 1-8. doi: https://doi.org/10.20546/ijcrbp.2017.407.001 